\title{
Biological control of Fusarium wilt on common beans by in-furrow application of Trichoderma harzianum
}

\author{
Daniel Diego Costa Carvalho ${ }^{1,4}$. Sueli Corrêa Marques de Mello ${ }^{2}$. \\ Irene Martins ${ }^{2} \cdot$ Murillo Lobo $\mathbf{J r}^{3}$
}

Received: 15 June 2015 / Accepted: 12 October 2015 / Published online: 12 November 2015

(C) Sociedade Brasileira de Fitopatologia 2015

\begin{abstract}
Two field trials were conducted during the summer and winter seasons of 2010 to evaluate the effect of biocontrol agents against Fusarium wilt of common bean. Treatments included six Trichoderma harzianum isolates applied in planting furrows at $1.2 \times 10^{12}$ conidia/ha, and one seed treatment with carboxin + thiram. Non-treated and infested plots served as control. Three T. harzianum isolates, CEN287, CEN290 and CEN316, reduced Fusarium wilt incidence and disease severity in the summer trial; incidence averaged 43.9 and $82.4 \%$ in effective treatments and infested control plots, respectively. During the winter season, four isolates, CEN290, 1306, CEN316 and CEN287, reduced wilt incidence by 22.4, 26.7, 41.2 and $51.3 \%$, respectively, compared to the infested control $(92.8 \%)$ and fungicide-treated seeds $(85.8 \%)$. In general, ranking of treatments were similar whether incidence or severity was evaluated. However, CEN287 and CEN316 were ranked as the most effective isolates in both seasons. Crop yield-related variables were not affected by the treatments. Fusarium oxysporum population in soil was positively associated with disease incidence and severity, and negatively associated with grain number per pod and 100-grain mass in the summer experiment. In the winter trial, increasing densities of
\end{abstract}

Section Editor: Trazilbo J. Paula Jr.

Murillo Lobo, Jr

murillo.lobo@embrapa.br

1 Departamento de Fitopatologia, Universidade de Brasília, 70910-700 Brasília, DF, Brazil

2 Embrapa Recursos Genéticos e Biotecnologia, 70770-900 Brasília, DF, Brazil

3 Embrapa Arroz e Feijão, 75375-000 Santo Antônio de Goiás, GO, Brazil

4 Universidade Estadual de Goiás, 75780-000 Ipameri, GO, Brazil
Trichoderma spp. in soil were correlated with increased 100grain mass and number of grains per pod. The results highlight the value of in furrow applications of biocontrol agents for managing Fusarium wilt of common bean.

Keywords Phaseolus vulgaris L · Antagonist delivery · Antagonist survival $\cdot$ Rhizocompetence $\cdot$ Soilborne plant pathogen $\cdot$ Vascular wilt

\section{Introduction}

Fusarium wilt (Fusarium oxysporum f. sp. phaseoli J.B. Kendr. \& W.C. Snyder) is one of the most important diseases of common bean worldwide (Schwartz et al. 2005). Root infections cause yellowing and wilt in plants especially at the blooming and pod-filling stages; the wilt is irreversible and the plants may eventually die prematurely. The disease is favored by mild temperatures and high soil moisture and can lead to yield reductions of $80 \%$ in susceptible common bean cultivars (Sartorato and Rava 1994; Salgado et al. 1996). Infested seeds and agricultural machinery are the main means of dissemination of the pathogen. In infested soils, diseased plants first appear in small patches, which tend to increase in the following cropping seasons. In the absence of effective disease management, the infested area gets larger and may expand throughout the entire field (Abawi and Pastor-Corrales 1990).

The pathogen survives as a saprophyte in soil or in plant debris in the form of chlamydospores, or even in roots of some non-host plants (Dhingra and Coelho-Neto 2001; Schwartz et al. 2005; Toledo-Souza et al. 2012). Successful disease management of susceptible cultivars is hardly achieved and there are few effective practices recommended for this disease (Hall and Nasser 1996), including host plant resistance 
(Alves-Santos et al. 2002). Chemical fungicides are ineffective and not recommended for vascular wilts (except for seed treatment) since they do not prevent further root infection and phloem colonization by the pathogen.

In a biocontrol strategy, rhizosphere colonization using beneficial microorganisms has been shown to protect different crops against wilt pathogens such as soybean, banana, cotton, chickpea (Khan et al. 2004; Thangavelu et al. 2004; Alabouvette et al. 2009; John et al. 2010; Pereg and McMillan 2015). However, data on the efficacy of antagonists against Fusarium wilt of common bean is lacking.

Seed treatment with Trichoderma species may protect seedlings against Fusarium wilt in common bean (Carvalho et al. 2014; Guimarães et al. 2014), but results based on field data are limited. Trichoderma antagonists combine different desired traits such as hyperparasitism, competition and antibiosis and survival on different soils, especially in the rhizosphere (Harman et al. 2004; Mohamed and Haggag 2006; John et al. 2010). Their identification requires a thorough selection and testing under disease-conducive weather.

Successful management of Fusarium wilt leading to yield loss reduction in commercial fields using competitive isolates of Trichoderma has been reported (Shali et al. 2010). Particularly in Brazil, the adoption of Trichoderma-based biofungicides has increased over the years due to their proven benefits in integrated management of white mold (Sclerotinia sclerotiorum) on different crops (Morandi and Bettiol 2009; Görgen et al. 2009; Geraldine et al. 2013; Aguiar et al. 2014). Nevertheless, there is an urgent need to test the usefulness of biocontrol for managing soilborne diseases such as root rots and vascular wilts. Beyond selection of competitive isolates, the delivery of antagonists at the target site is a critical step in a biocontrol program (Glare et al. 2012). Among the different methods of antagonist release, in-furrow application is a lowcost and promising alternative (Teixeira et al. 2012). Therefore, our study aimed to evaluate the efficacy of six Trichoderma harzianum isolates applied via in-furrow method to suppress Fusarium wilt and reduce $F$. oxysporum population in soil.

\section{Materials and methods}

\section{Origin of T. harzianum and $F$. oxysporum f. sp. phaseoli isolates}

The effects of six $T$. harzianum isolates and a seed treatment with a commercial fungicide mixture were compared to infested non-treated plots. A non-infested and non-treated plot served as negative control. Isolates CEN287, CEN288, CEN289, CEN290 and CEN316 were previously selected for rhizocompetence, production of volatile metabolites and hyperparasitism (Carvalho et al. 2011, 2014) and recovered from the culture collection of biocontrol agents of Embrapa Genetic Resources and Biotechnology (Brasília, Federal District, Brazil). The commercial isolate T. harzianum ' 1306 ' (Itaforte Bioprodutos, Itapetininga, Brazil), registered in Brazil for the biocontrol of common bean root rots was also tested.

The experimental units consisted of field plots $\left(1 \mathrm{~m}^{2}\right)$ infested with an aggressive $F$. oxysporum $\mathrm{f}$. sp. phaseoli race 2 isolate (Fop 46) used as standard in breeding for disease resistance (Cândida et al. 2009). This isolate is deposited in the collection of fungal and functional microorganisms from Embrapa Arroz e Feijão (Santo Antônio de Goiás, Goiás State, Brazil). All fungal isolates used in this work were stored in liquid nitrogen and sterilized filter paper at $-20^{\circ} \mathrm{C}$, respectively, and recovered on Potato-Dextrose-Agar (PDA) before application.

\section{Growth of $F$. oxysporum f. sp. phaseoli and T. harzianum}

Soil infestation was accomplished with two different methods to provide sufficient inoculum for disease development. In the first, macro and microconidia were produced by transferring four PDA disks with Fop 46 mycelia to $250 \mathrm{~mL}$ Erlenmeyers with $50 \mathrm{~mL}$ of Tochinai media ( $10 \mathrm{~g}$ Bacteriological Peptone; $0.5 \mathrm{~g} \mathrm{KH}_{2} \mathrm{PO}_{4} ; 2.5 \mathrm{~g} \mathrm{MgSO}_{4} .7 \mathrm{H}_{2} \mathrm{O} ; 20$ g Maltose; $1000 \mathrm{~mL}$ distilled water). Flasks were kept in an orbital shaker at $120 \mathrm{rpm}$ and room temperature during 4 days. In the second method, chlamydospores and conidia of Fop 46 isolate were produced on 9:1 sand:cornmeal medium, after 20 days of growth at $25 \pm 2{ }^{\circ} \mathrm{C}$ (Nene and Haware 1980).

Six $5 \mathrm{~mm}$ agar plugs of $T$. harzianum isolates were removed from 7-day-old colonies and transferred to $250 \mathrm{~mL}$ flasks containing $15 \mathrm{~g}$ of autoclaved parboiled rice, previously moistened at $60 \%$. Flasks were incubated at $25{ }^{\circ} \mathrm{C}$ and $12 \mathrm{~h}$ photoperiod. After 6 days, conidia were harvested by shaking colonized grains with autoclaved distilled water, and filtered through sterile gauze.

\section{Field experiments}

Field trials were conducted in the summer and winter of 2010 at the experimental area of Embrapa Arroz e Feijão in a field previously cropped with common bean. For both trials, plots were infested with a suspension of macroconidia and microconidia adjusted to $1.3 \times 10^{6}$ colony-forming units (CFU) /mL using a Neubauer chamber. This suspension was used in consecutive soil infestations with $F$. oxysporum $\mathrm{f}$. sp. phaseoli (Sivan and Chet 1986), using a $3.8 \mathrm{~L}$ manual compression sprayer, made on 14 and 27 Nov 2009, 12 and 19 Dec 2009, 8 and 22 Jan 2010, 22 Apr 2010 and 20 May 2010. The last soil infestation was made in furrows simultaneously with the sowing of common bean susceptible cultivar BRS Valente (19 Dec 2009 and 22 Apr 2010). Each plot consisted 
of two planting furrows of approximate $0.1 \mathrm{~m}$ depth, spaced $0.5 \mathrm{~m}$, which received 15 seeds of susceptible cultivar BRS Valente per linear meter.

Thereafter, planting furrows were sprayed with T. harzianum isolates $\left(1.2 \times 10^{12}\right.$ conidia/ha) using a handheld sprayer of $1.0 \mathrm{~L}$. Immediately after spraying, furrows were covered with a 2-3 cm soil layer and sprinkle irrigated. Finally, to ensure $F$. oxysporum f. sp. phaseoli density in soil, an extra infestation was made 20 days after sowing (DAS) at V2 phenological stage, by careful addition to the bean lines chlamydospores and conidia obtained in sand:cornmeal, after adjustment to $1.5 \times 10^{6} \mathrm{CFUs} / \mathrm{mL}$.

Soil was prepared with a hoe and kept free of weeds throughout the experiment. Fertilization consisted of NPK (5-30-15 at $400 \mathrm{~kg} / \mathrm{ha}$ ) with nitrogen topdressing of $60 \mathrm{~kg} / \mathrm{ha}$ at the V3 stage. Other cultural practices followed regional recommendations (Paula Júnior et al. 2008). The summer trial was rain fed with sprinkle irrigation used only when necessary to avoid water stress. The winter trial was irrigated daily, since the season is typically dry in central-western Brazil. Treatments were assigned to the same plots in the summer and winter trials.

The trials were conducted in a randomized block design with four replications. Both trials had control treatments with in-furrow spraying of sterilized water. Carboxin + thiram $(300 \mathrm{~mL} / 100 \mathrm{~kg}$ of seeds, containing $200 \mathrm{~g} / \mathrm{L}$ of carboxin; $200 \mathrm{~g} / \mathrm{L}$ of thiram) is commonly used by farmers of the country to manage soilborne diseases of common bean and so it was included as a treatment. Since we aimed to test whether Trichoderma-based treatments reduce Fusarium wilt as an eco-friendly approach, further in-furrow treatments with chemicals were not considered for testing. A negative control was included, that is, inoculated with neither the pathogen nor the antagonist.

\section{Quantification of $F$. oxysporum and Trichoderma from rhizosphere soil}

Composite samples with approximately $200 \mathrm{~g}$ of rhizospheric soil were collected at $0-10 \mathrm{~cm}$ depth to estimate initial and final populations of both $F$. oxysporum and Trichoderma spp. The same procedure was used to quantify population density of $F$. oxysporum during the crop cycle. Soil samples were carefully homogenized and stored at $4{ }^{\circ} \mathrm{C}$, before laboratory procedures. Such procedures involved quantification of overall $F$. oxysporum and Trichoderma spp. soil populations in semi-selective media. Even though such media do not track specific Trichoderma strains or Fusarium formae specialis, they are useful to compare treatments according to the inoculum density of soil fungi (Bakarat and Al-Masri 2009; Zachow et al. 2009; Martínez-Medina et al. 2010; Zhou and Wu 2012).
Inoculum density of $F$. oxysporum during the course of the experiments was assessed by 1:100 serial dilution of soil samples in sterilized water and spread of $1 \mathrm{~mL}$ aliquots on Komada semi-selective media (20.0 g D-Galactose; 2.0 g LAsparagine; $1.0 \mathrm{~g} \mathrm{KH}_{2} \mathrm{PO}_{4} ; 0.5 \mathrm{~g} \mathrm{KCl} ; 0.5 \mathrm{~g} \mathrm{MgSO}_{4} .7 \mathrm{H}_{2} \mathrm{O}$; $10 \mathrm{mg} \mathrm{Fe}_{3} \mathrm{Na}$ EDTA; $18.0 \mathrm{~g}$ agar; $750 \mathrm{mg}$ PCNB; $1.0 \mathrm{~g}$ $\mathrm{Na}_{2} \mathrm{~B}_{4} \mathrm{O}_{7} \cdot 10 \mathrm{H}_{2} \mathrm{O} ; 1000 \mathrm{~mL}$ distilled water). With the same dilution procedure, density of Trichoderma spp. was estimated in TSM $\left(0.12 \mathrm{~g} \mathrm{KH}_{2} \mathrm{PO}_{4} ; 0.26 \mathrm{~g} \mathrm{MgSO}_{4} .7 \mathrm{H} 2 \mathrm{O} ; 0.26 \mathrm{~g}\right.$ $\mathrm{KNO}_{3} ; 1.0 \mathrm{~g} \mathrm{CaCl}_{2} .2 \mathrm{H}_{2} \mathrm{O} ; 1.0 \mathrm{~g} \mathrm{Ca}\left(\mathrm{NO}_{3}\right)_{2} ; 0.05 \mathrm{~g}$ citric acid; $1.0 \mathrm{ml}$ igepal; $2.0 \mathrm{~g}$ saccharose; $18.0 \mathrm{~g}$ agar; $0.0025 \mathrm{~g}$ vinclozolin; $1000 \mathrm{ml}$ distilled water). Trichoderma spp. and F. oxysporum were identified according to colony morphology and morphological traits, and their population density was expressed in CFUs/g .

\section{Disease assessment}

Fusarium wilt incidence on common beans was assessed in all plants at 64-67 DAS (R7 phenological stage), always in the morning, based on the proportion of plants with typical disease symptoms. Further, wilt severity was estimated with an ordinal scale ranging from 1 to 9 (Pastor-Corrales and Abawi 1987), as follows: 1 - no visible symptoms; 3 - one to three leaves, representing no more than $10 \%$ of total foliage with wilt and chlorosis; 5 and 7 - plants respectively with approximately 25 and $50 \%$ of wilting and chlorotic leaves; and 9 dead or severely infected plants with wilt, chlorosis, necrosis and/or premature defoliation. Disease scores were further used to calculate a disease severity index (DSI), according to McKinney (1923): $(\mathrm{DSI})=[\mathrm{S}$ ( score in the scale $\times$ frequency $) /$ (total number of units $\times$ maximum score in the scale) $] \times 100$.

\section{Common bean yield}

The crop was harvested at R9 stage in 14 Mar (summer trial) and $16 \mathrm{Jul}$ (winter trial) 2010 and grain yield from all manually harvested plants from each plot was expressed in $\mathrm{kg} / \mathrm{ha}$. The number of seeds per pod and 100-grain mass were assessed in 10 plants selected at random from each plot.

\section{Statistical analysis}

Data of all variables were checked for normality (ShapiroWilk test) and further subjected to analysis of variance (Anova). Data on yield in the summer trial, wilt incidence in winter trial and pathogen population density in both trials were transformed to $\sqrt{x}+0.5$ in order to normalize data and stabilize variances prior to Anova. Data on the progress curve of $F$. oxysporum in soil was modeled using linear regression. The Dunnet test $(P \leq 0.05)$ was used to compare mean of each treatment with the control mean. Pearson's 
correlation coefficient was calculated for all pairs of variables assessed in the trials. All statistical procedures were performed with R software (R Development Core Team, Vienna, Austria).

\section{Results}

Increasing levels of $F$. oxysporum were achieved by the sequential soil infestation and growth of a susceptible cultivar (BRS Valente), thus providing a disease-conducive environment. Endemic populations of $F$. oxysporum averaged around $50 \mathrm{CFUs} / \mathrm{g}$ (Fig. 1) prior to first infestation, and reached a maximum of nearly $300 \mathrm{CFUs} / \mathrm{g}$. A second order linear model $\left(r^{2}=0.96, P \leq 0.01\right)$ was fitted to data on population density of F. oxysporum in the check plots. In contrast, mean initial population of Trichoderma spp. was close to $10 \mathrm{CFUs}$, and therefore the differences in biocontrol efficacy were attributed to treatment effects.

All plots showed yellowed and wilted plants at the R7 stage in both trials, with varying disease incidence, even in the noninfested plots. The successful soil infestation led to 57.5 and $26.1 \%$, on average, of Fusarium wilt incidence and severity index, respectively, in the summer trial (Fig. 2). Disease levels increased 66.3 and $29.7 \%$ on average for disease incidence and severity in the winter trial. In the Fop 46-infested control plots, wilt incidence was 2.97 and 5.83 times higher than noninfested plots, respectively in the summer and winter trials.

CEN287, CEN290 and CEN316 significantly reduced wilt incidence in the summer trial compared to the infested and non-treated control, while CEN288, CEN289, 1306 and carboxin + thiram did not differ from the control. In this

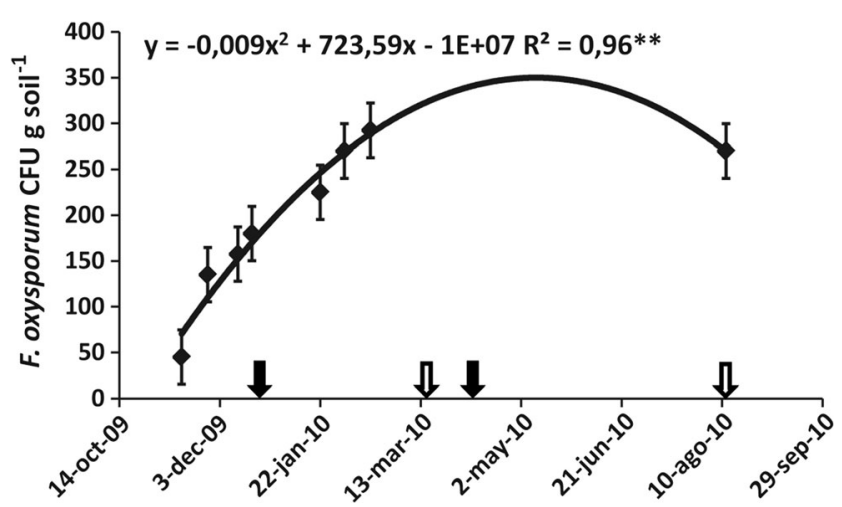

Fig. 1 Progress of Fusarium oxysporum colony forming units (CFUs)/g soil on control microplots infested with Fusarium oxysporum f. sp. phaseoli without any treatments. Black and white arrows indicate respectively planting and harvest dates of common bean 'BRS Valente', in two consecutive experiments. The adjusted model represents the buildup of $F$. oxysporum after standard soil infestation procedures in both trials: with a $1.3 \times 10^{6}$ macro and micro conidia $/ \mathrm{mL}$ suspension of F. oxysporum f. sp. phaseoli at November 14, 27, December 12, 19 (2009) and January 8, 22 April 22 and May 20 (2010). Complementary soil infestation was done with a suspension of conidia and chlamydospores adjusted to $1.5 \times 10^{6} \mathrm{CFUs} / \mathrm{mL}$ (SC) on January 8 and May $20,2010 .{ }^{*}$ Significant according to $\mathrm{F}$ test $(P \leq 0.01)$ season, infested plots averaged $82.4 \%$ wilt incidence, with 36.8 mean disease severity. Trichoderma-based treatments reduced incidence and severity by 47.1 and $20.7 \%$ (CEN287), 47.1 and $22.7 \%$ (CEN290), 37.5 and $20.4 \%$ (CEN316), respectively. The non-infested and non-treated control plot averaged 27.7 and $17.5 \%$ of incidence and severity, respectively.

In the winter trial, with increased inoculum levels, all treatments showed high disease intensity levels despite the $15.9 \%$ of symptomatic plants in non-infested and non-treated plot (Fig. 2). CEN290, 1306, CEN287 and CEN316 reduced disease incidence by $22.4,26.7,45.0$ and $55.0 \%$, respectively, compared to the infested plot. Furthermore, CEN287 and CEN316 also achieved severity similar to the negative control (correspondingly 24.3, 20.9 and $14.6 \%$ ), lower than others treatments, where severity ranged from 28.3 to $40.5 \%$. Moreover, other Trichoderma treatments did not differ from infested control. In both trials, means of wilt incidence and DSI did not differed between fungicide-treated and the infested control.

Common bean mean yield ranged from 2941 to $3664 \mathrm{~kg} \mathrm{ha}^{-1}$ and 3336 to $3948 \mathrm{~kg} \mathrm{ha}^{-1}$, respectively in the summer and winter trial, without differences among treatments. Also, there were no differences concerning yield components, in both trials. The pathogen/antagonist ratio was not affected by growing season and data from both trials were combined for analysis (Fig. 3). Isolates CEN 288 and CEN290 were ineffective to reduce Fusarium wilt. With the exception of these two isolates, for both trials, the highest population density of Trichoderma spp. corresponded to the lowest $F$. oxysporum density, assessed in treatments at crop harvest.

Regarding the $F$. oxysporum $\times$ Trichoderma spp. relationship, treatments were apparently clustered in four different groups: 1) enduring population of Trichoderma spp. with higher reduction of $F$. oxysporum on CEN287 treatment, corresponding to the best biocontrol results of Fusarium wilt; 2) CEN289, CEN316 and 1306 isolates forming an intermediate group, with recovered populations of Trichoderma spp. between 40 and 80 CFUs; 3 ) infested control with the pathogen; and 4) chemical seed treatment, with the smallest population of Trichoderma spp. and the highest of $F$. oxysporum. The final population of $F$. oxysporum in the Fop 46-infested plots treated with $T$. harzianum CEN287 (62 CFUs) was at levels similar to the initial density of $F$. oxysporum determined prior to the establishment of the trials.

Correlation analysis showed distinct associations among disease variables, fungal populations and yield components (Table 1). F. oxysporum density in soil was positively correlated to Fusarium wilt incidence and severity in the summer $2009 / 2010$ ( $\rho=0.78$ and $\rho=0.66$, respectively), but negatively associated to 100 -grain mass $(\rho=-0.71$ ) and number of grains per pod $(\rho=-0.69)$ in the same trial. In 2010 winter, 100-grain 


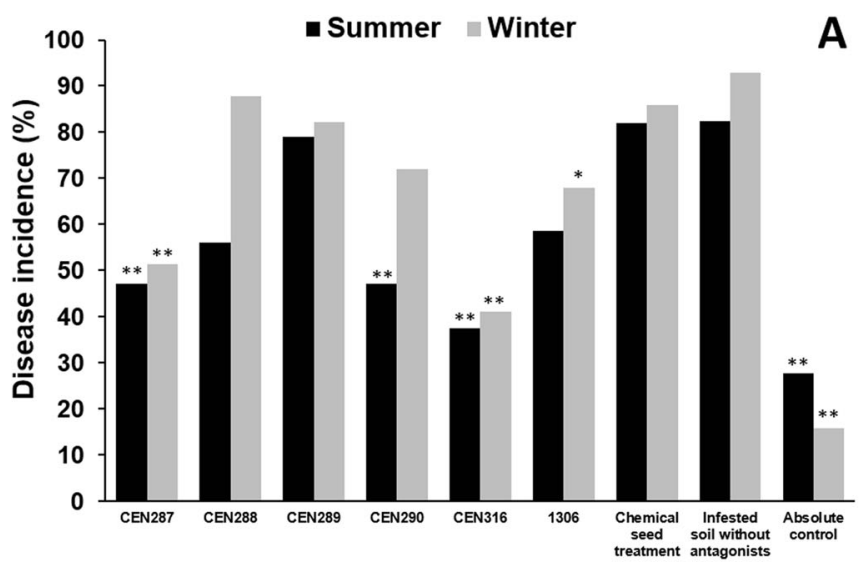

Fig. 2 Effect of Trichoderma harzianum isolates on Fusarium wilt incidence (a) and disease severity index (b), assessed in field microplots cropped with common bean 'BRS Valente', in the summer

mass and number of grains per pod were positively correlated to Trichoderma spp. density in soil, respectively with $\rho=0.67$ $(P \leq 0.05)$ and $\rho=0.97(P \leq 0.01)$. Also in the winter trial, the number of pods per plant was negatively correlated to DSI $(\rho=0.74, P \leq 0.05)$.

\section{Discussion}

Successive sowing of annual crops in our study increased density of Fusarium population in soil at levels similar to previous reports of increase of $F$. solani $\mathrm{f}$. sp. phaseoli population (up to 400 propagules/g of soil) after the first growing of common bean (Hall and Phillips 1992). Although the plating methods used here did not allow to differentiate Fop 46 isolate from endemic $F$. oxysporum isolates, the inoculum density of

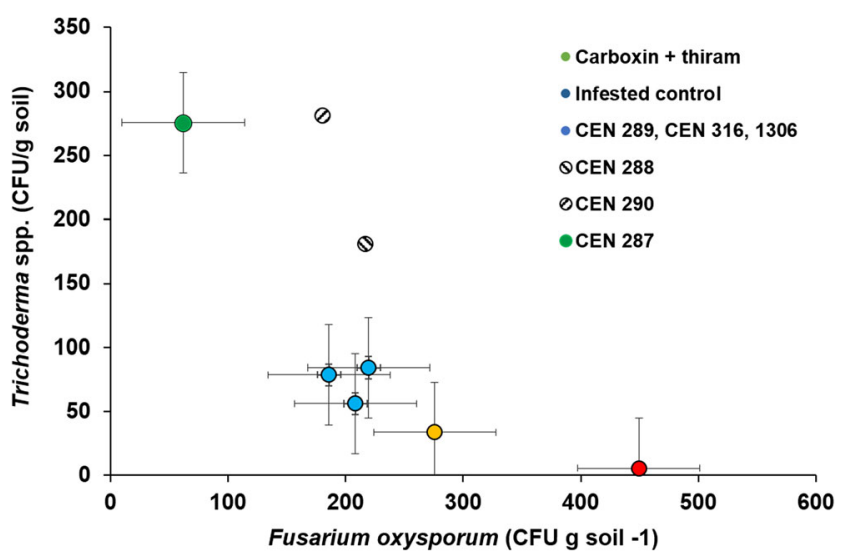

Fig. 3 Scatter plot of Fusarium oxysporum density in relation to Trichoderma spp. density on experimental microplots after in-furrow treatment with Trichoderma harzianum isolates, in contrast to seeds treated with carboxin + thiram and control plots. Fungal populations were assessed at harvest of common bean 'BRS Valente', in a joint analysis with results from 2009/2010 (summer) and 2010 (winter) season

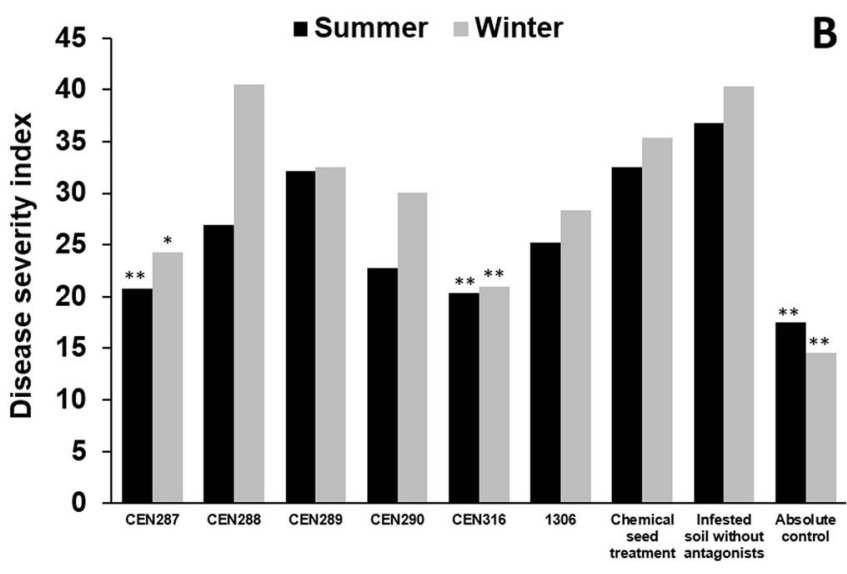

2009/2010 and winter 2010 season. * and ** are significant at 5 and $1 \%$, according to the Dunnet test, in comparison to non-treated infested microplots

wilt-booster isolates on infested control was sufficient to achieve disease incidence at levels well above the noninfested plots. With the natural increase of $F$. oxysporum $\mathrm{f}$. sp. phaseoli in infected plants and survival in soil, the soil infestation during winter trial was probably ineffective, as Fusarium populations almost reached a plateau in the second bean-growing season.

The pod-filling (R7) is the growth stage when treatments aiming to reduced inoculum density and vascular wilt progress are evaluated (Toledo-Souza et al. 2012). In the case of biocontrol treatments, antagonist survival until such advanced stage of crop development is a quite needed trait. Despite the nearly $300 \mathrm{CFUs} / \mathrm{g}$ of $F$. oxysporum during the onset of the winter trial, and the former Fusarium wilt records, the disease development followed the same patterns in this season (Fig. 2), probably favored by temperatures around $20^{\circ} \mathrm{C}$ and high soil moisture.

Correlation analysis supported biocontrol results, and the relevance in reducing the pathogen inoculum density to improve disease control and increase yields. CEN287 and CEN316 were the most effective isolates to reduce wilt incidence and DSI in the two trials. Among the six T. harzianum isolates, only these two have shown hyperparasitic capacity against $F$. oxysporum f. sp. phaseoli (Carvalho et al. 2014). Their higher effectiveness relates to the fact that biocontrol does not rely solely on plant-microorganism interactions, but also on the ecological adaptability required to survive on soil and protect infection sites (Alabouvette et al. 2009; Longa et al. 2009). Therefore, our findings suggest that only T. harzianum CEN287 fulfilled the requirements for plant protection and antagonist survival in soil, in comparison to other treatments.

Although differences up $723 \mathrm{~kg} / \mathrm{ha}$ in yield were found among treatments, there was no significant difference corroborating previous findings (Hoyos-Carvajal et al. 2009; Vinale 
Table 1 Pearson's correlation coefficients for all pairs of variables Fusarium wilt incidence (INC), disease severity index (DSI), number of pods per plant (NP), 100-grain mass (GM), crop yield (YLD), number of grains per pod (NGP), density (units/g soil) of Fusarium oxysporum
(Fox) and Trichoderma spp. (Tricho) - evaluated in two experiments conducted in the summer (shaded lower left panel) and winter (nonshaded upper right panel) of 2010 year. Numbers in bold represent significance at $5 \%$ probability

\begin{tabular}{lcccccccc}
\cline { 2 - 8 } & INC & SEV & NP & GM & YLD & NGP & Foxy & Tricho \\
\hline INC & & $\mathbf{0 . 9 8}$ & $\mathbf{- 0 . 6 3}$ & -0.24 & -0.26 & -0.01 & $0.58-$ & -0.01 \\
SEV & $\mathbf{0 . 9 5}$ & & $\mathbf{- 0 . 7 4}$ & -0.27 & -0.43 & -0.08 & 0.53 & -0.08 \\
NP & -0.30 & -0.16 & & 0.56 & $\mathbf{0 . 7 9}$ & 0.47 & -0.51 & 0.52 \\
GM & -0.34 & -0.21 & 0.57 & & 0.23 & 0.49 & -0.60 & $\mathbf{0 . 6 7}$ \\
YLD & -0.30 & -0.16 & $\mathbf{0 . 9 9}$ & 0.57 & & 0.37 & -0.06 & 0.36 \\
NGP & -0.27 & -0.10 & $\mathbf{0 . 9 0}$ & 0.56 & $\mathbf{0 . 8 9}$ & & -0.24 & $\mathbf{0 . 9 7}$ \\
Foxy & $\mathbf{0 . 7 8}$ & $\mathbf{0 . 6 6}$ & -0.59 & $\mathbf{- 0 . 7 1}$ & -0.58 & $\mathbf{- 0 . 6 9}$ & & -0.36 \\
Tricho & -0.32 & -0.22 & 0.59 & -0.11 & 0.58 & 0.52 & -0.27 & \\
\hline
\end{tabular}

et al. 2009). Previous studies reported significantly greater yield return for crops at stressed rather than non-stressed environments (Harman et al. 2004).

The final population of Trichoderma spp. in plots treated with CEN287 was seven times higher than the infested control plots, and corresponded to the lowest population density of F. oxysporum. These results are also in accordance with Mohamed and Haggag (2006), who reported reductions in Fusarium oxysporum f. sp. lycopersici levels under greenhouse and field soil using seeds treated with T. harzianum and respective reductions in tomato wilt incidence.

In summary, we demonstrated the effectiveness of biocontrol of Fusarium wilt of common bean with $T$. harzianum. The in-furrow application of biocontrol treatments provided satisfactory control using CEN287 and CEN316 isolates at levels above seed treatment with fungicides. These findings corroborate results by Prasad et al. (2002) and Bora et al. (2004), and suggest this strategy as a feasible alternative for managing Fusarium wilt. Other practices could be integrated into a biocontrol program aiming to improve crop health and providing new standards of disease management where other techniques are inefficient.

Acknowledgments Thanks are given to Dr. Anne Sitarama Prabhu for critically reviewing the manuscript. Authors are grateful to the National Council for Scientific and Technological Research $(\mathrm{CNPq})$ for a graduate scholarships for the first author and a research grant 578604/2008-6 to senior author, and to Federal District Research Foundation (FAP-DF) for financial support.

\section{References}

Abawi GS, Pastor-Corrales MA (1990) Root rots of beans in Latin America and Africa: Diagnosis, research methodologies, and management strategies. Centro Internacional de Agricultura Tropical (CIAT), Cali
Aguiar RA, Cunha MG, Lobo Junior M (2014) Management of white mold in processing tomatoes by Trichoderma spp. and chemical fungicides applied by drip irrigation. Biol Control 74:1-5

Alabouvette C, Olivain C, Migheli Q, Steinberg C (2009) Microbiological control of soil-borne phytopathogenic fungi with special emphasis on wilt-inducing Fusarium oxysporum. New Phytol 184:529-544

Alves-Santos FM, Cordeiro-Rodrigues L, Sayagués JM, MartínDomínguez R, García-Benavides P, Crespo MC, Díaz-Mínguez JM, Eslava AP (2002) Pathogenicity and race characterization of Fusarium oxysporum f. sp. phaseoli isolates from Spain and Greece. Plant Pathol 51:605-11

Bakarat RM, Al-Masri M (2009) Trichoderma harzianum in combination with sheep manure amendment enhances soil suppressiveness of Fusarium wilt of tomato. Phytopathol Mediterr 48:385-395

Bora T, Özaktan H, Göre E, Aslan E (2004) Biological control of Fusarium oxysporum f. sp. melonis by wettable powder formulations of the two strains of Pseudomonas putida. J Phytopathol 152: $471-475$

Cândida DV, Costa JGC, Rava CA, Carneiro MS (2009) Controle genético da murcha do fusário (Fusarium oxysporum) em feijoeiro comum. Trop Plant Pathol 34:379-394

Carvalho DDC, Mello SCM, Lobo Junior M, Geraldine AM (2011) Biocontrol of seed pathogens and growth promotion of common bean seedlings by Trichoderma harzianum. Pesqui Agropecu Bras 46:822-828

Carvalho DDC, Lobo Junior M, Martins I, Inglis PW, Mello SCM (2014) Biological control of Fusarium oxysporum f. sp. phaseoli by Trichoderma harzianum and its use for common bean seed treatment. Trop Plant Pathol 39:384-391

Dhingra OD, Coelho-Neto RA (2001) Reservoir and non-reservoir host of bean-wilt pathogen. Fusarium oxysporum f. sp. phaseoli. J Phytopathol 149:463-467

Geraldine AM, Lopes FAC, Carvalho DDC, Barbosa ET, Rodrigues AR, Brandão RS, Ulhoa CJ, Lobo Junior M (2013) Cell wall-degrading enzymes and parasitism of sclerotia are key factors on field biocontrol of white mold by Trichoderma spp. Biol Control 67:308-316

Glare T, Caradus H, Gelernter W, Jackson T, Keyhani N, Köhl J, Marrone P, Morin L, Stewart A (2012) Have biopesticides come of age? Trends Biotechnol 30:250-258

Görgen CA, Silveira Neto AN, Carneiro LC, Ragagnin V, Lobo Junior M (2009) Controle do mofo-branco com palhada e Trichoderma harzianum 1306 em soja. Pesqui Agropecu Bras 44:1583-1590

Guimarães GR, Pereira FS, Matos FS, Mello SCM, Carvalho DDC (2014) Supression of seed borne Cladosporium herbarum on 
common bean seed by Trichoderma harzianum and promotion of seedling development. Trop Plant Pathol 39:401-406

Hall R, Nasser LCB (1996) Practice and precept in cultural management of bean diseases. Can J Plant Disease 18:176-185

Hall R, Phillips LG (1992) Effects of crop sequence and rainfall on population dynamics of Fusarium solani f. sp. phaseoli in soil. Can J Bot 70:2005-2008

Harman GE, Howell CR, Viterbo A, Chet I, Lorito M (2004) Trichoderma species - opportunistic, avirulent plant symbionts. Nat Rev Microbiol 2:43-56

Hoyos-Carvajal L, Orduz S, Bissett J (2009) Growth stimulation in bean (Phaseolus vulgaris L.) by Trichoderma. Biol Control 51:409-416

John RP, Tyagi RD, Prévost D, Brar SK, Pouleur S, Surampalli RY (2010) Mycoparasitic Trichoderma viride as a biocontrol agent against Fusarium oxysporum f. sp. adzuki and Pythium arrhenomanes and as a growth promoter of soybean. Crop Prot 29:1452-1459

Khan MR, Khan SM, Mohiddin FA (2004) Biological control of Fusarium wilt of chickpea through seed treatment with the commercial formulation of Trichoderma harzianum and/or Pseudomonas fluorescens. Phytopathol Mediterr 43:20-25

Longa CMO, Savazzini F, Tosi S, Elad Y, Pertot I (2009) Evaluating the survival and environmental fate of the biocontrol agent Trichoderma atroviride SC1 in vineyards in northern Italy. J Appl Microbiol 106: $1549-1557$

Martínez-Medina A, Pascual JA, Pérez-Alfocea F, Albacete A, Roldán A (2010) Trichoderma harzianum and Glomus intraradices modify the hormone disruption induced by Fusarium oxysporum infection in melon plants. Phytopathology 100:682-688

McKinney RH (1923) Influence of soil temperature and moisture on infection of wheat seedlings by Helminthosporium sativum. J Agric Res 6:195-218

Mohamed HALA, Haggag WM (2006) Biocontrol potential of salinity tolerant mutants of Trichoderma harzianum against Fusarium oxysporum. Braz J Microbiol 37:181-191

Morandi MAB, Bettiol W (2009) Controle biológico de doenças de plantas no Brasil. In: Bettiol W, Morandi MAB (eds) Biocontrole de doenças de plantas: uso e perspectivas. Embrapa Meio Ambiente, Jaguariúna, pp 7-14

Nene YL, Haware MP (1980) Screening chickpea for resistance to wilt. Plant Dis 64:379-380

Pastor-Corrales M, Abawi GS (1987) Reaction of selected bean germplasm to infection by Fusarium oxysporum f. sp. phaseoli. Plant Dis 71:990-993

Paula Júnior TJ, Vieira RF, Teixeira H, Coelho RR, Carneiro JES, Andrade MJB, Rezende AM (2008) Informações técnicas para o cultivo do feijoeiro-comum na região central brasileira: 2007 2009. EPAMIG-CTZM, Viçosa

Pereg L, McMillan M (2015) Scoping the potential uses of beneficial microorganisms for increasing productivity in cotton cropping systems. Soil Biol Biochem 80:349-358

Prasad RD, Rangeshwaran R, Hegde, Anuroop CP (2002) Effect of soil and seed application of Trichoderma harzianum on pigeonpea wilt caused by Fusarium udum under field conditions. Crop Prot 21: 293-297

Salgado MO, Schwartz HF, Brick MA (1996) Inheritance of resistance to a Colorado race of Fusarium oxysporum $\mathrm{f}$. sp. phaseoli in common beans. Plant Dis 79:279-281

Sartorato A, Rava CA (1994) Murcha ou amarelecimento de Fusarium. In: Sartorato A, Rava CA (eds) Principais doenças do feijoeiro comum e seu controle. Embrapa-SPI, Brasília, pp 175-190

Schwartz HF, Steadman JR, Hall R, Foster RL (2005) Compendium of bean diseases, 2nd edn. APS Press, St. Paul

Shali A, Ghasemi S, Ahmadian G, Ranjbar G, Dehestani A, Khalesi N, Motallebi E, Vahed M (2010) Bacillus pumilus SG2 chitinases induced and regulated by chitin, show inhibitory activity against Fusarium graminearum and Bipolaris sorokiniana. Phytoparasitica 38:141-147

Sivan A, Chet I (1986) Biological control of Fusarium spp. in cotton, wheat and muskmellon by Trichoderma harzianum. J Phytopath 116:39-47

Teixeira H, Paula Júnior TJ, Vieira RF, Silva MB, Ferro CG, Lehner M (2012) Trichoderma spp. decrease Fusarium root rot in common bean. Summa Phytopathol 38:334-336

Thangavelu R, Palaniswami A, Velazhahan R (2004) Mass production of Trichoderma harzianum for managing fusarium wilt of banana. Agric Ecosyst Environ 103:259-263

Toledo-Souza EDS, Silveira PM, Café Filho AC, Lobo Junior M (2012) Fusarium wilt incidence and common bean yield according to the preceding crop and the soil tillage system. Pesqui Agropecu Bras 47: $1031-1037$

Vinale F, Flematti G, Sivasithamparam K, Lorito M, Marra R, Skelton BW, Ghisalberti EL (2009) Harzianic acid, an antifungal and plant growth promoting metabolite from Trichoderma harzianum. J Nat Prod 72:2032-2035

Zachow C, Berg C, Müller H, Meincke R, Komon-Zelazowska M, Druzhinina I, Kubicek CP, Berg G (2009) Fungal diversity in the rhizosphere of endemic plant species of Tenerife (Canary Islands): relationship to vegetation zones and environmental factors. The ISME Journal 3:79-92

Zhou X, Wu F (2012) p-Coumaric acid influenced cucumber rhizosphere soil microbial communities and the growth of Fusarium oxysporum f.sp. cucumerinum Owen. Plos One 7:1-11 